
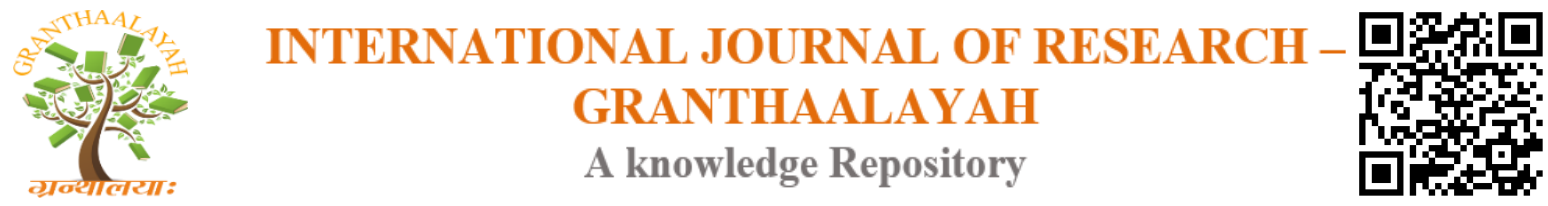

Management

\title{
RELATIONSHIP OF CAREER DEVELOPMENT WITH EMPLOYEE PERFORMANCE IN PT HONDAMOTOR INDONESIA
}

\author{
Nahason Sitohang *1 \\ ${ }^{*}$ STIE YPBI, Jakarta, Indonesia
}

\begin{abstract}
This research was conducted at PT Honda Motor Indonesia, with the title: Relationship Career development with employee performance at PT Honda Motor Indonesia. The purpose of this study was to determine the relationship between career development and employee performance at PT. Honda Motor Indonesia. The research method used was an explanatory survey method with a correlational approach where in the process of collecting data a direct observation was conducted on the company in the form of observation and questionnaire distribution. Career development is an employee activity that helps employees in planning their future careers in the company so that the company and the employees concerned can develop themselves to the maximum. Employee Performance is the spirit of work that is the desire and sincerity of someone doing a good job and being disciplined to achieve maximum work performance. The linear regression test is $\mathrm{y}=51.82$ $+0.656 \mathrm{X}$ and the correlation test is 0.458 which means that the effect is quite strong. Test the coefficient of determination of $20.97 \%$ and the remaining $79.03 \%$ influenced by other factors. The hypothesis test is $t$ arithmetic $=3.573$ and t table 0.279 means $t$ arithmetic $>$ from $t$ table then Ho is rejected and $\mathrm{Ha}$ is accepted which means there is a strong enough relationship between career development with employee performance.
\end{abstract}

Keywords: Career Development; Employee Performance.

Cite This Article: Nahason Sitohang. (2019). "RELATIONSHIP OF CAREER DEVELOPMENT WITH EMPLOYEE PERFORMANCE IN PT HONDAMOTOR INDONESIA.” International Journal of Research - Granthaalayah, 7(9), 268-280. 10.29121/granthaalayah.v7.i9.2019.610.

\section{Introduction}

\subsection{Preliminary}

Employee performance in the company leads to the ability of employees to carry out the overall tasks that are the responsibility. An employee's performance is said to be good if he has high work motivation, can complete the tasks given on time, always contributes and has a good attitude and behavior according to work standards that have been determined both by the company and the values that apply in his environment work. Performance can be influenced by several factors, namely internal factors and external factors. Internal factors are factors that come from within the 
employee. While external factors are supporting factors for employees in working from the environment, for example career development.

Career development is an employee activity that helps employees in planning their future careers in the company so that the company and the employee concerned can develop themselves to the maximum (Mangkunegara, 2004). Individuals who want their career to develop must work as much as possible, namely by showing good performance. Meanwhile, the leadership as a party that facilitates the career development of employees should be able to provide a clear career development path in the context of achieving company goals and employee career development activities is very important in efforts to improve employee performance.

Resigning becomes a last resort when someone feels discomfort in a job. There are various reasons for this, from salary mismatches to a less comfortable work environment to more attractive offers from other companies.

Some time ago, Career news conducted a survey to find out in general, what is the reason someone decided to resign from his job. From the survey results, the three highest polls underlying a resign from a job are that there is no clarity in career path, salary mismatch, and mismatch with the work environment.

Unclear career path turns out to be the highest cause someone decides to resign from his job. As many as 49.60 percent of respondents said that. According to Arnika Heydi, Sinar Mas Payroll Supervisor, careers must be built in the right company. "A career in the wrong place can kill our potential to level up faster," he said.

In addition, as reported by the Refined Analytics Indonesia research institute, career paths are related to the future of careers. Company employees prioritize career path clarity in order to have clear goals and objectives at work. Career path is essential enough to determine the future of your career.

The reason for resigning related to career path is also related to reasons for salary mismatch. According to Arnika, certain career paths affect the amount of salary that will be received. In a poll conducted by Career news, 42.40 percent of respondents said the salary mismatch was a good reason to submit a resign. Salary is an important reason because it relates to rewards for employee contributions to the company. Even so, salaries become the basic needs of working people. The third reason for the Career news poll was related to the incompatibility of the company's culture and work system. As many as 38.30 percent of respondents chose this reason. However, no doubt, the three reasons are felt in one package by an employee so that the decision to resign is more mature. "I decided to resign because I got a material offer and a better position in the company with better management," said Arnika. Career news polling data shows that 80 percent of respondents who have submitted a resign have come from companies on the island of Java. From this percentage, the highest resign rate is in DKI Jakarta province with a percentage of 23.45 percent. While the province of Central Java as much as 19.13 percent. DIY occupies the third highest position with a percentage of 13.27 percent, only a slight difference with West Java, 12.97 percent. 
While the percentage of resigned employees coming from companies outside Java is only 20 percent. The highest province in our poll regarding resign issues outside of Java is Central Kalimantan, which is 2.7 percent.

Although 80 percent of respondents who have applied for resigns are from Java, the reasons for their decision to resign tend to be the same as employees who work outside Java.

At this time in the midst of an era of increasingly stringent competencies, every company is required to remind its performance in order to win the competition. The main key to performance is how a company is able to develop human resources (HR). In one of the private companies in Jakarta, there are some employees who have questions related to the career path system that employees will get in the future period. The existence of information or a full explanation of the career path system for employees will make it easier for employees to know the terms and conditions or direction for career paths in the company and can reduce employee turnover rates. However, if a career level system is not established, employees who are already working will not know the direction of achieving their careers in the future, so that it can affect the turn of employees' internal motivation in working. With a decrease in internal motivation in employees can hamper business and non-business development in the company. In the first quarter of 2017 , there were already 4 employees in the company who decided to resign. After being confirmed with the company's HRD, the career path system that has not yet been implemented is one of the several factors of the employee's resigences. Therefore, to reduce the level of employee overruns and decrease the internal motivation of employees, the company must follow up the career path system to be applied in the company so that business growth the company is increasing and growing well

\subsection{Human Resource Management.}

Understanding Human Resources (HR) is a productive individual who works as an activator of an organization, both within institutions and companies that have the function of assets so that they must be trained and developed. Understanding macro human resources in general consists of two, namely macro human resources, namely the number of people in productive age in an area, and micro human resources in the narrow sense, namely individuals who work at an institution or company. Human Resources (HR) is a matter which is very important and must be had in an effort to achieve organizational or company goals. Human resources are the main element of the organization compared to other elements of resources such as capital, technology, because humans themselves control other factors.

Human resources currently have a large influence on a company which is now in a changing business environment that is difficult to predict and is no longer in a stable business environment. Companies must be flexible no longer be rigid (organizational rigidity). Business activities are no longer run based on rules alone, but are also controlled by vision and values. Therefore, it requires the ability of human resources that can be relied on, which has the same insight, creativity, knowledge, and vision as the company's vision. The development of human resource capabilities (HR) can be adjusted to the scenario of the Company's business strategy, and the master plan for leadership (Human Capital). Increased competence of human capital can be through a number of education and training programs, such as those focused on: a) Leadership development; b) The 
Company's strategic objectives are in accordance with the scenarios and work plans of all of the Company's business units; c) Closing competency gaps between employees

\subsection{Carer Development}

\section{Definition of Career Development.}

An individual who first accepts a job offer will have procurement is different about work, compared to individuals who have worked for a long time. Those who have worked for a long time will have a broader and more meaningful view. The perception of work is changing not only as a source of income, but also as something that other desires can have, such as appreciation from others, competition for power and higher positions. In connection with this, every employee must be given the opportunity to develop his career, namely as a tool to motivate them to perform better. Career is the whole position or position that may be occupied by someone in the organization in his work life, and career goals are the highest position someone will occupy in an organization. Here are some career definitions and career development proposed by experts: According to Robert L. Mathis - John H. Jackson (2006: 342) argues that career understanding is as follows:

Career is a series of positions related to work occupied by a person throughout his life". There are a number of principles that need to be considered in relation to career development. First, the job itself has the most influence on career development, because every time a different challenge arises, what is learned from work can be far more important than formally planned development activities. Second, the type of new skills that will be required is determined by specific job requirements. Third, development will not occur if someone has not acquired the skills required by a particular position.

\section{Career Development Stages}

Some people consider a career as a promotion within an organization. The word "career" can be viewed from several different perspectives. From one perspective, careers are sequences of positions held by a person during his lifetime. This is an objective career. However, from another perspective a career consists of changes in values, attitudes, and motivations that occur because a person gets older. This is a subjective career. Both perspectives, objective and subjective, are focused on the individual. Both perspectives assume that people have some level of control over their destiny, so they can change opportunities to maximize the success and satisfaction that comes from their careers. This perspective further assumes that human resource activities must recognize the career stage, and help employees with the development task they face at each career stage. The stages of career development according to Henry Simamora (2004: 416) are as follows:

1) Early career is the first stage where someone enters an organization. During the getting-in phase, employees strive to obtain a realistic picture of the organization, and find work that best suits their expertise, experience, preferences, and interests. Early careers do not always run smoothly. Therefore at this stage it is the emphasis stage on attention to get a guarantee of meeting the needs in the early years of work. In addition, the company should encourage its employees to participate in self-assessment exercises, and should assist them in determining realistic and flexible career paths and formulating career plans.

2) Mid career is a stage where every individual will experience a transition or change in their career. In the middle stage, the individual reviews his achievements to date and the possibility of achieving his personal career and future life goals. One strategy to address 
mid-career problems is to train employees in mid-career to foster more junior employees. The development of a generation of leaders in the future can be a significant, permanent, and very satisfying contribution. Another strategy for overcoming mid career problems is to face or prevent obsolescence. To solve this problem, one way is to send employees to seminars, workshops, training. Furthermore, three personal characteristics tend to be associated with low levels of obsolescence: high intellectual abilities, high self-motivation, and personal flexibility.

3) The final career is a turning point for productivity, or decline and early retirement, can follow a mid-career crisis. Productive individuals can assume the role of senior staff or top management, or they may remain contributors in non-leadership roles. For most employees, the main tasks of the late career period are to remain productive and prepare for effective retirement. To adjust to the final career successfully, individuals should maintain a positive attitude, think ahead, and receive social support from work relatives and their spouses. Employees at the end of their careers should be involved in long-term financial planning and find time to have fun with their life partners and plan their retirement carefully.

\section{Career Development Process}

Many people assume that a career is the same as progress in an organization. Careers contain two main focuses, namely: internal focus and external focus. internal focus refers to the way a person views his career. While the external focus refers to a series of positions that are actually occupied by a worker. To understand career development in an organization requires testing of two main processes, namely:

1) Career planning. How do people plan and realize their own career goals. This is a deliberate attempt by someone to become more aware and aware of their own skills, interests, values, opportunities, obstacles, choices, and their consequences. This process includes the effort to identify goals and / or goals related to career, and the determination of plans to realize these goals.

2) Career Management. This process refers to how the organization designs and implements its career development program. This process is more a formal, organized, and planned effort to achieve a balance between individual career desires and organizational workforce requirements. So it is more a mechanism to realize the needs of human resources now and in the future.

\section{Career Development Objectives}

In general, the aim of all career development programs is to match employee needs and goals with career opportunities available in the company today and in the future. This is in line with what was stated by Veitzal Rivai (2004: 291) that a well-designed career development will help in determining their own career needs and adjusting the needs of employees with company goals. The career development goals stated by Andrew J. Dubrin (1982: 198) cited by Anwar Prabu Mangkunegara (2000: 77) are as follows:

a) Help sin achieving individua and company goals.

Career development helps the achievement of company goals and individual goals. A successful employee with excellent work performance then occupies a higher position, this means that the 
company's goals and individual goals are achieved. Organizational Career Development, Career Management, Career Planning.

b) Show employee welfare relationships. The company plans employee careers by increasing their welfare so that employees have higher loyalty.

c) Help employees realize their potential abilities Career development helps to make employees aware of their ability to occupy certain positions according to their potential and expertise.

d) Strengthening the relationship between employees and the company. Career development will strengthen employee relationships and attitudes towards the company.

e) Prove social responsibility. Career development is a way to create a positive work climate and employees become more mentally healthy.

f) Help strengthen the implementation of company programs. Career development helps other company programs so that company goals are achieved.

g) Reducing turn over and staffing costs. Career development can make turnover low and so can staffing costs be more effective.

h) Reducing professional and managerial obsolescence. Career development can prevent professional and managerial obsolescence and boredom.

i) Enhances the analysis of all employees. Career development is intended to integrate work planning and staffing.

j) Activating a thought (view) of long distance. Career development is associated with long distances. This is because the placement of a position requires requirements and qualifications in accordance with its portion.

\section{Forms of Career Development}

The forms of career development depend on the career path planned by each organization. How a company determines a career path for its employees depends on the needs and situation of the company itself, but so generally what companies often do is through education and training, promotion and mutation. Understanding of these three things can be explained below:

1) Education and training is a company activity that is intended to improve and develop the attitudes, behavior, skills and knowledge of employees according to the wishes of the company concerned.

2) Promotion is a change of position or position from a lower level to a higher level, this change will usually be followed by an increase in one's responsibilities, rights, and social status.

3) Mutation is part of a process of activities that can develop one's position or status in an organization. The term mutation itself or which in some literature is referred to as transfer in the narrow sense can be formulated as a change from a position in a class to a position in another class that is not higher or lower (at the same level) in the salary plan.

\section{Elements of Career Development.}

The preparation of a career development program for workers in an organization must be carried out by taking into account various possibilities that seek to strike a balance between the interests of the individual workforce and the interests of the community (in this case the organization), so that career development is expected to produce benefits for both parties. For individual workforce, it is expected that career development will be able to improve the quality of their lives from time 
to time. As for the organization, the expected benefit is guaranteed quality of human resources owned and their optimal use to realize organizational goals. In this regard, Edwin B. Flippo mentions that there are 3 (three) elements that must be considered in the steps of preparing a career development program, as quoted by Bambang Wahyudi (2002: 163), namely:

\section{1) Estimating career needs (Career need assessment).}

Career for someone is a very important element and is very personal in his life. In the preparation of career development programs, assessing individual career needs is the first element said first, because it is precisely this element that will greatly affect the realization of the main goals of career development programs, namely maintaining existing human resources so that they will continue to have a willingness to work in organizations with a high enough intensity.

\section{2) Career opportunities.}

After the workforce is encouraged to determine their career needs, it is only natural that it is followed by responsibility to describe career opportunities that exist within the organization concerned. With information about career opportunities that exist in the organization, then every workforce and prospective workforce knows clearly the various possible positions that can be occupied.

\section{3) Adjustment of Career Needs and Opportunities (Need - opportunity alignment)}

If the two previous elements, namely the career needs of the workforce and available career opportunities have been determined, then what must be done is to make adjustments between the two interests. In practice, adjustments this can be done with the help of a labor mutation program or training program and workforce development.

\section{Factors That Influence Career Development.}

How ever good a career plan that has been made by a worker accompanied by reasonable and realistic career goals, the plan will not become a reality without systematic career development. Although the human resources manager can play a role in the development activities, the most responsible is actually the workers themselves. This is one of the most fundamental career development principles. According to Sondang P. Siagian (2006: 215) factors that influence an employee's career development are:

1) Job Performance.

The most important factor to improve and develop a career of an employee is his work performance in carrying out the tasks entrusted to him. Without satisfactory work performance, it is difficult for a worker to be suggested by his supervisor to be considered for promotion to a higher job or position in the future.

2) Introduction by other parties.

It is the various authorities who decide whether or not a person is to be promoted such as a direct superior and the head of the staffing department who know the ability and work performanc of an employee

3) Loyalty to th organization. It is the dedication of an employee who wants to continue working in the organization where he works for a long time.

4) Counselors and sponsors. Guidance is a person who provides advice or suggestions to employees in an effort to develop their career. While the sponsor is someone within an educational institution that can create opportunities for employees to develop their careers.

5) Support of subordinates. It is the support given by subordinates in the form of success of the relevant manager's tasks

6) Opportunity to grow. 
Is an opportunity given to employees to improve their abilities, both through training, courses, and also continue their education.

7) Resignation It is an employee's decision to stop working and turn to other educational institutions that provide greater opportunities to develop a career.

\subsection{Employee Job Satisfaction}

1) Definition of Job Satisfaction.

Based on the opinion of Keith Davis, Wexley, and Yuki quoted by Anwa Prabu Mangkunegara (2000: 117) mentioned above, that job satisfaction is a feeling of support or does not support employees who are related to their work or with their condition. Work-related feelings involve aspects such as wages or salaries received, career development opportunities, relationships with other employees, job placement, type of work, company organizational structure, quality of supervision. While the feelings associated with him, among others, age, health conditions, abilities, and education. According to T. Hani Handoko (1994: 193) defines job satisfaction as follows:

"A pleasant or unpleasant emotional state in which employees view their work." Based on the definitions above, a conclusion can be drawn that job satisfaction is a person's personal attitude towards work arising from his work environment based on his perception of his work and aspects seen in the work.

\section{Job Satisfaction Theory}

Job satisfaction theory according to Anwar Prabu Mangkunegara (2000:120) is as follows:

\section{1) Equity Theory}

This theory was developed by Adam. The components of this theory are input, outcome, comparison person, and equity-in-equity. According to this theory, satisfaction or dissatisfaction is the result of comparing his input-outcome with comparison of other employee's input (comparison person). So if the comparison is felt balanced (equity) then the employee will feel satisfied. However, if there is an imbalance (inequity) can lead to two possibilities, namely over compensation inequity (and imbalances that benefit him), and vice versa under compensation inequity (imbalances that benefit other employees who are comparison or comparison person).

\section{2) Discrepancy Theory}

This theory was first spearheaded by Proter. He believes that measuring satisfaction can be done by calculating the difference between what should be the reality felt by employees. If what the employee gets turns out to be greater than what is expected then the employee becomes satisfied. Conversely, if the employee gets lower than expected, will cause the employee to be dissatisfied.

3) Need fulfillment theory (Need Fulfillment Theory).

According to this theory, employee job satisfaction depends on whether or not the employee's needs are met. The employee will feel satisfied if he gets what he needs. The greater the employee's needs are met, the more satisfied the employee is. Vice versa if the employee's needs are not met, the employee will feel dissatisfied. 
4) Group view theory (Social Reference Group Theory).

According to this theory, employee job satisfaction does not depend on meeting the needs alone, but very much depends on the views and opinions of groups that employees consider to be a reference group. The reference group is used by employees as a benchmark to assess themselves and their environment. Thus, employees will feel satisfied if their work results are in accordance with the interests and needs expected by the reference group.

5) The two-factor theory from Herzberg (Second Factor Theory From Herzberg).

The two-factor theory was developed by Frederick Herzberg. He uses the theory of Abraham Maslow as a reference point. Herzberg's research was conducted by conducting interviews with the subjects of engineers and accountants. Each subject was asked to tell the events experienced by them both pleasant (giving satisfaction) and unpleasant (not giving satisfaction). Then analyzed with content analysis (content analysis) to determine the factors that cause satisfaction or dissatisfaction.

6) Exceptions Theory.

Hope theory was developed by Victor H. Vroom. Hope is the strength of belief in a treatment that is followed by specific results. This illustrates that employee decisions that allow achieving one result can lead to other results. Hope is an action related to results, from $0-1$ range. If the employee feels it is impossible to get a result, the expectation is 0 . If the action is related to a certain result, the expectation is worth 1 . The employee's expectation is normally between $0-1$.

\section{Factors That Affect Job Satisfaction}

Many factors affect employee job satisfaction. Factors related to or determining job satisfaction are that work is not just about doing work, but it is also related to other aspects such as interactions with coworkers, superiors, following certain rules and work environment that are often inadequate. The above shows that one's job satisfaction is influenced by many factors, not only salary, but related to the work itself. There are two factors that affect job satisfaction, namely factors that exist in employees and work factors.

1) Employee factors, namely intelligence (IQ), special skills, age, gender, physical condition, education, work experience, years of service, personality, emotions, ways of thinking, perceptions, and work attitudes.

2) Job factors, namely the type of work, organizational structure, rank (class), position, quality of supervision, financial security, job promotion opportunities, social interaction, and work relations.

The factors used in job satisfaction according to Marihot Tua EfendimHariandja (2002: 291) are as follows:

1) Salary, which is the amount of payment a person receives as a result of carrying out work. 2) The work itself, that is the content of work done by someone. 3) Co-workers, ie friends who always interact in the implementation of work. 4) Boss, which is someone who always gives orders or instructions in carrying out work. 5) Promotion, i.e. the possibility that someone can develop through promotion. 6) Work environment, namely the physical and psychological environment. Job satisfaction reflects one's feelings about their work. To increase job satisfaction, companies must respond to employee needs by developing a mechanism that gives employees full opportunities in making decisions and planning their work lives. Measurement of Job Satisfaction. 
Measurement of job satisfaction is used to determine the level of employee job satisfaction. Measuring job satisfaction can be used a job description index scale, a job satisfaction scale based on facial expressions, and a Minnesota job satisfaction questionnaire. The measurement of job satisfaction according to Anwar Prabu Mangkunegara (2000: 126) is as follows:

1) Measurement of job satisfaction with a job description index scale This measurement scale was developed by Smith, Kendal, and Hulin in 1969. In its use, employees were asked about jobs and positions that were felt to be very good and very bad, on a scale measuring the attitudes of five areas, namely work, supervision, wages, promotions, and co-worker. Every question asked, must be answered by the employee by marking the answeryes, no, or no answer.

2) 2)Measurement of job satisfaction based on facial expressions.

Measuring job satisfaction was developed by Kunin in 1955. This scale consists of a series of pictures of people's faces ranging from very happy, happy, neutral, sullen, and very sullen. Employees are asked to choose facial expressions that are in accordance with the conditions of work felt at the time.

3) Measurement of job satisfaction with the Minnesota questionnaire This work satisfaction measurement was developed by Weiss, Dawis, and England in 1967. This scale consists of work that is felt to be very dissatisfied, dissatisfied, neutral, satisfying, and very satisfying. Employees are asked to choose an alternative answer in accordance with the conditions of work.

\section{Effect of Career Development on Job Satisfaction}

Employee job satisfaction in a company has a significant share in achieving the company's goals and objectives that have been set. High job satisfaction is desired by managers because it can be associated with the positive results they expect. High job satisfaction is a sign that an organization is well managed and is basically the result of effective behavioral management. Thus, a company or organization in achieving its goals must be able to pay attention to job satisfaction of its employees which includes their hopes and needs. If what is expected by the employee with the fact that there are no gaps or only a small gap means there is still satisfaction in the employee. Through career development will help employees achieve their own job satisfaction. With this assessment will be able to know the positive and negative characteristics that exist in a person who will spur a strong impetus to further enhance work ability, both by using positive traits as capital or with a systematic effort to eliminate or slightly reduce the traits its negative characteristics. Through career opportunities and adjustments between internal employees' existing careers in their implementation, these adjustments can be made with the help of employee mutation programs and education and training programs. With this program employees are expected to be able to add insight, experience, abilities and expertise so that it will increase employee job satisfaction. From the description above, it seems clear that career development has an effect on employee job satisfaction. This is supported by the opinion of Harry Indra (2001) from the following journal: "To create high job satisfaction in employees, factors that are significantly influential are needed, namely factors related to working conditions, factors relating to coworkers, factors related to supervision, factors related to career development and factors related to salary (Harry Indra, 2001). "The influence between career development and employee job satisfaction is also supported by the opinions of Wexley and Yukl (1997) from the following journals.:

"Job satisfaction as" the way an employee feels about his or her job ". This means that job satisfaction is how employees feel about themselves or their work. it can be concluded that job 
satisfaction is a feeling that supports or does not support the employee in relation to work or his condition. Work-related feelings involve aspects such as efforts, career development opportunities, relationships with other employees, work placement, and organizational structure. Meanwhile, feelings related to him include age, health conditions, abilities and education. According to Veitzhal Rivai (2004: 299), the fundamental goal of a career development program is to help employees analyze their abilities and interests in adjusting between the needs to grow and develop with the needs of the company. Career development is also crucial where management can increase productivity, improve employee attitudes towards work and build higher job satisfaction. From the description above it appears that career development is influential in increasing employee job satisfaction.

\section{Research Methodology}

This research was conducted at PT Honda motor Bekasi Indonesia with a number of hypotheses of 500 respondents and with Sugiono's theory, the sample took $10 \%$ of the population then the sample amounted to 50 respondents randomly, the research method used was the field reserch method by holding observations directly to the object of research and distributing quoisier, besides using the library research method by taking references from scientific books, theses and theses. Data collection from questionnaire responses is then processed by analyzing data using a simple linear regression analysis, correlation test, coefficient of determination test, and hyposis test.

\section{Discussion Result}

\section{Determine Simple Linear Regression}

To be able to analyze the relationship between variable $\mathrm{X}$ (leadership style) and $\mathrm{Y}$ variable (employee morale). By using the following formula:

$\mathrm{Y}=\mathrm{a}+\mathrm{bX}$

With the following data : $\mathrm{n}=50, \sum \mathrm{X}=2963, \sum \mathrm{Y}=2582, \sum X^{2}=177163, \sum Y^{2}=134230, \sum X . \mathrm{Y}$ $=153554$.

$$
\begin{aligned}
& a=\frac{\left(\sum Y\right)\left(\sum X^{2}\right)-\left(\sum X\right)\left(\sum X Y\right)}{n\left(\sum X^{2}\right)-\left(\sum X\right)^{2}} \\
& \boldsymbol{a}=\frac{(\mathbf{2 5 8 2} \cdot \mathbf{2 9 6 3})-(\mathbf{2 9 6 3 . 1 5 3 5 5 4})}{(\mathbf{5 0 . 2 9 6 3})-(\mathbf{2 9 6 3})^{2}}=51,82 \\
& b=\frac{n \cdot\left(\sum y\right)\left(\sum x y\right)-\left(\sum x\right)\left(\sum y\right)}{n \cdot\left(\sum X^{2}\right)-\left(\sum X\right)^{2}} \\
& b=\frac{(50.2582)(153554)-(2963.2582)}{(50.2963)-2963^{2}}=0,656
\end{aligned}
$$

So: $\mathrm{Y}=\mathrm{a}+\mathrm{bX}$ is $\mathrm{Y}=51.82+0.656 \mathrm{X}$, then the regression equation from the results of a simple regression analysis obtained equation means that every time there is a change in the unit score of 
variable $\mathrm{X}$, will be followed by changes in the value of variable $\mathrm{Y}$ by 0.656 times, then increase 0.656 score of the variable work performance of employees.

\section{Correlation Test}

Correlation Analysis Correlation analysis is used to measure the closeness of the relationship between variable $\mathrm{X}$ (career development) with $\mathrm{Y}$ variable (employee performance), then the Pearson Product Moment correlation coefficient formula is used as follows: $r_{x y}=$

$$
\begin{gathered}
\frac{\left(n \sum x y\right)-\left(\sum x\right)\left(\sum y\right)}{\sqrt{\left\{n \sum x^{2}-\left(\sum x\right)^{2}\right\}}\left\{n \sum y^{2}-\left(\sum y\right)^{2}\right\}} \\
r_{x y}=\frac{(50.153554)-(2963.2582)}{\sqrt{\left\{50.177163-\left(2963^{2}\right)\right\}}\left\{50.134230-\left(2582^{2}\right)\right\}}=0,458
\end{gathered}
$$

From the calculation results it can be seen that there is a positive influence where the value of reliability between variable $\mathrm{X}$ (career development) with $\mathrm{Y}$ variable (employee work performance) is 0.458 . So the reliability value exceeds $r_{-}$(table) 0.05 which is 0.279 , meaning that the level of career development relationships is quite strong. The following table shows the correlation coefficient of $r$, which is a measure of the reliability calculation results above.

\section{Coefficient of Determination}

Research using the test of determination is intended to find out how much the presentation of the relationship of career development (X) with employee work performance (Y), then the calculation of the coefficient of determination of the value of $\mathrm{r}$ is used with the following formula: $\mathrm{KD}=r^{2} \mathrm{x}$ $100 \%$. $\mathrm{KD}=0,458^{2} \times 100 \%=20,97 \%$

Thus, the results of the study use the coefficient of determination, showing that the relationship of career development with employee performance is $20.97 \%$ and the rest is influenced by other factors.

\section{Hypothesis Test}

Ho: $r=0$ (there is no relationship between career progression and employee work performance). $\mathrm{Ha}: \mathrm{r}>0$ (there is a relationship of career development with employee work performance).

\section{Looking for Arithmetic}

The formula used to find $t$ arithmetic is: $t_{\text {count it }}=\frac{r \sqrt{n-2}}{\sqrt{1-r^{2}}} \cdot t$ count it $=\frac{0,458 \sqrt{50-2}}{\sqrt{1-(0,458)^{2}}}=3,57$.Look for ttables. Having known t_count then $t$ _count is compared with the value of $t$ table. Significant error level used (a) $=5 \%$ two-party test and degrees of freedom $(\mathrm{dk})=\mathrm{n}-2$. With the critical value of the test can be obtained from the distribution table $t$ with the following formula: for $\mathrm{t}-\mathrm{a}(\mathrm{dk}=\mathrm{n}-$ 2 ) then the table $=0.279$ is obtained. 


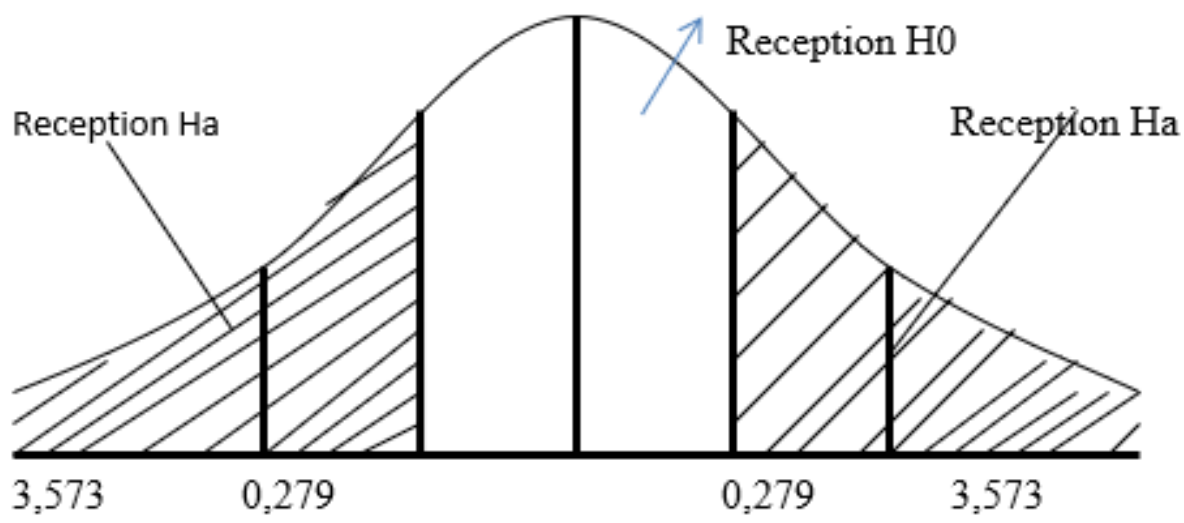

\section{Conclusions and Suggestions}

\section{Conclusions}

1) Based on the Linear Regression test results, namely $a=51.82, b=0.656$, then the linear regression is $\mathrm{Y}=51.82+0.656 \mathrm{X}$.

2) Based on the results of the study obtained a Correlation Coefficient value of 0.458 . Which means there is a sufficient relationship between career development with the work performance of employees of PT. Yamaha Motor Indonesia.

3) Based on the results of the study obtained a coefficient of determination of $20.97 \%$ which means that the contribution or contribution of career development to the work performance of employees is $20.97 \%$ while the remaining $79.03 \%$ is influenced by other variables that are outside the scope of the study.

4) Based on the results of the hypothesis test obtained t value of 3.573 and t table of 0.279 . because the value of $t$ arithmetic $>t$ table $(3.573>0.279)$ it can be concluded that at the 95\% confidence level there is a relationship between career development with employee work performance.

\section{Suggestions}

1) In order for employee performance to improve, the company should pay attention to employee career development.

2) Career development for employees must pay attention to the length of work of employees, education, employee loyalty.

3) Career development is also accompanied by facilities and salary increases for employees.

4) Career development also needs to be adjusted to the rights of employees in the company.

\section{References}

[1] Hasibuan, Malayu, SP (2000, Human Resource Management, Hasibuan, Malayu, SP (2002), Jakarta,BumiAksara.

[2] Rivai, Veithzal (2004, Human Resource Management for Companies, Jakarta, PT. Raja Grafindo,Persada.

[3] Hariandja Marihot Tua E (2002), Human Resource Management, Procurement, Development, Compensation, and Increased Employee Productivity, Bumi Aksara, Jakarta. Simamora, Henry (2004 Human Resource Management,), Bina Aksara, Jakarta. 